\title{
On the determination of the bending fatigue strength in and above the very high cycle fatigue regime of shot-peened gears
}

\author{
D. Fuchs ${ }^{1}$ D $\cdot$ S. Schurer ${ }^{2,3}$ (D) $\cdot$ T. Tobie $^{1}$ D $\cdot$ K. Stahl ${ }^{1}$ \\ Received: 16 March 2021 / Accepted: 28 May 2021 / Published online: 28 June 2021 \\ (c) The Author(s) 2021
}

\begin{abstract}
Demands on modern gearboxes are constantly increasing, for example to comply with lightweight design goals or new $\mathrm{CO}_{2}$ thresholds. Normally, to increase performance requires making gearboxes and powertrains more robust. However, this increases the weight of a standard gearbox. The two trends therefore seem contradictory. To satisfy both of these goals, gears in gearboxes can be shot-peened to introduce high compressive residual stresses and improve their bending fatigue strength. To determine a gear's tooth root bending fatigue strength, experiments are conducted up to a defined number of load cycles in the high cycle fatigue range. However, investigations of shot-peened gears have revealed tooth root fracture damage initiated at non-metallic inclusions in and above the very high cycle fatigue range. This means that a further reduction in bending load carrying capacity has to be expected at higher load cycles, something which is not covered under current standard testing conditions. The question is whether there is a significant decrease in the bending load carrying capacity and, also, if pulsating tests conducted at higher load cycles—or even tests on the FZG back-to-back test rig-are necessary to determine a proper endurance fatigue limit for shot-peened gears. This paper examines these questions.
\end{abstract}

D. Fuchs

fuchs@fzg.mw.tum.de

1 Gear Research Center (FZG), Technical University of Munich, Boltzmannstraße 15, 85748 Garching, Germany

2 Former member of the Gear Research Center (FZG), Technical University of Munich, Garching, Germany

3 MAN Truck \& Bus SE, Munich, Germany 


\section{Zur Bestimmung der Zahnfußfestigkeit kugelgestrahlter Zahnräder im Bereich erhöhter Lastspielzahlen}

\section{Zusammenfassung}

Die Anforderungen an moderne Getriebe steigen stetig, zum Beispiel um Leichtbauziele oder neue CO2-Grenzwerte erfüllen zu können. Getriebe und Antriebsstrang müssen daher in der Regel eine erhöhte Tragfähigkeit und gleichzeitig eine hohe Zuverlässigkeit aufweisen. Dadurch erhöht sich jedoch meist das Gewicht eines Standardgetriebes. Die beiden Trends scheinen also widersprüchlich. Um beide Ziele zu erfüllen, können Zahnräder in Getrieben kugelgestrahlt werden, um hohe Druckeigenspannungen einzubringen und ihre Zahnfußfestigkeit zu verbessern. Um die Zahnfußtragfähigkeit eines Zahnrades zu bestimmen, werden üblicherweise Versuche bis zu einer definierten Grenzlastspielzahl im Bereich der angenommenen Dauerfestigkeit durchgeführt. Untersuchungen im Bereich höherer Lastspielzahlen an kugelgestrahlten Zahnrädern zeigen jedoch im Gebiet der angenommenen Dauerfestigkeit Zahnfußbrüche, die an nicht-metallischen Einschlüssen initiiert wurden. Dies bedeutet, dass bei höheren Lastspielzahlen mit einem weiteren Abfall der Zahnfußtragfähigkeit gerechnet werden muss, was mit den derzeitigen Standardprüfbedingungen nicht erfasst wird. Es stellt sich nun die Frage, ob es bei höheren Lastspielzahlen zu einem signifikanten Abfall der Zahnfußtragfähigkeit kommt und ob Pulsatorversuche oder sogar Versuche in Zahnrad-Laufprüfständen notwendig sind, um eine Dauerfestigkeitsgrenze für kugelgestrahlte Zahnräder zuverlässig zu ermitteln. Die vorliegende Veröffentlichung geht diesen Fragen nach.

\section{Abbreviations \\ FVA German Drive Technology Research Association (registered association) \\ SEP Steel test specification}

\section{Introduction}

Over the last 10 years, new registrations of passenger cars increased by approx. $21 \%$ in Germany for the segment above $100 \mathrm{~kW}$ (see Fig. 1). The trend is not restricted to Germany but is also apparent worldwide. A second trend is that more and more lightweight passenger cars are being constructed, for example with the aim of improving $\mathrm{CO}_{2}$ figures and to satisfy EU regulations. To ensure increased performance, the gearbox and powertrain have to be made more robust, which, however, increases the weight of common gearboxes. The two trends would therefore appear contradictory.

To achieve both goals, gears in gearboxes can be shotpeened. The high compressive residual stresses introduced by the shot-peening process have the effect of increasing the tooth root load carrying capacity, because the strain

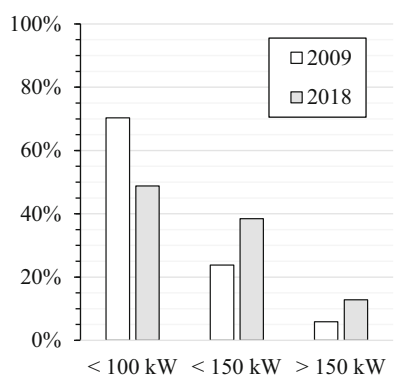

Fig. 1 New registrations of passenger cars in Germany in 2009 and 2018 divided into performance categories based on the data of $[1,2]$ maximum is no longer at the surface but below it. The research findings presented in [3-5] show that the tooth root load carrying capacity of (duo-)shot-peened gears can be increased by up to $48 \%$ compared to unpeened gears. The consequence of this is that a higher torque can be transmitted. In some cases, it is also possible to make the gearbox smaller. This reduces not only the weight of the gearbox but also that of the car as a whole. However, there is one drawback. As the strain maximum is below the surface, the crack initiation is often no longer at the surface but below it, for example, at a non-metallic inclusion.

Experimental tests are typically carried out to determine the tooth root bending strength of gears. A limiting number of 3 million (see [6]) or 6 million (see [7]) load cycles, respectively, is usually chosen for pulsator testing. For most gear materials, this range is considered the beginning of the long-life strength range. However, research has shown that with shot-peened gears, tooth root fracture damage still occurs at such non-metallic inclusions in and above the very high cycle fatigue range. This means that a further reduction in load carrying capacity is expected at higher load cycles, something which is not covered in the reference fatigue tests. The question is whether there is a significant decrease in bending load carrying capacity and, also, if pulsating tests at higher load cycles - or even tests on the FZG back-to-back test rig - are necessary to determine a proper endurance fatigue limit of shot-peened gears. This paper investigates these questions. 

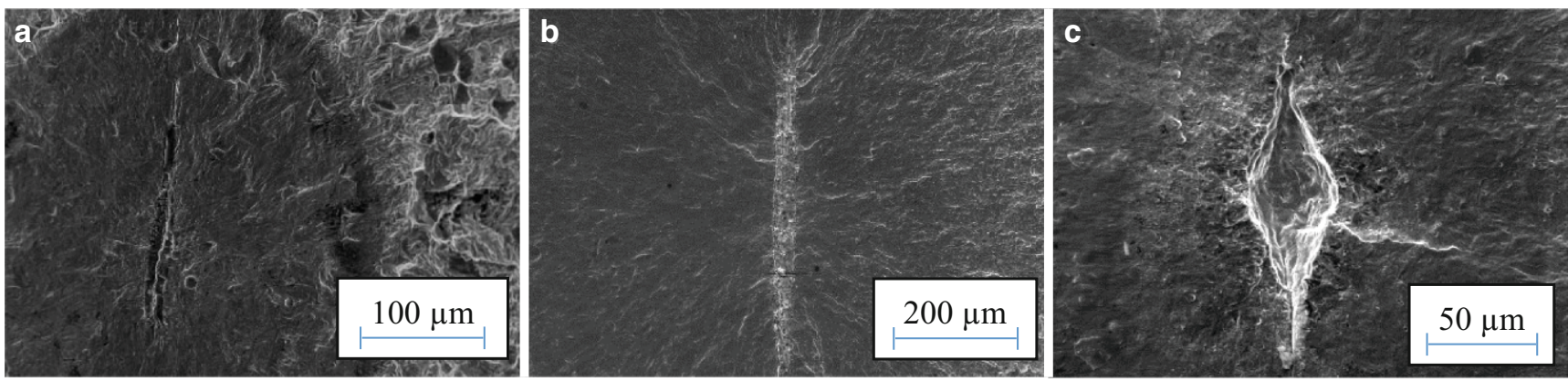

Fig. 2 Typical non-metallic inclusions in gear steels. a Oblong manganese sulfide in MnCr-alloyed steel. b Oblong aluminum oxide in CrNiMoalloyed steel. c Spherical aluminum oxide in CrNiMo-alloyed steel

Fig. 3 Influence of inspection plane on apparent inclusion size [13] a

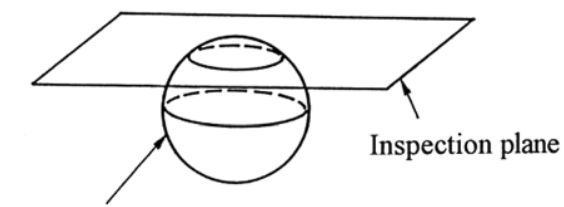

Spherical inclusion

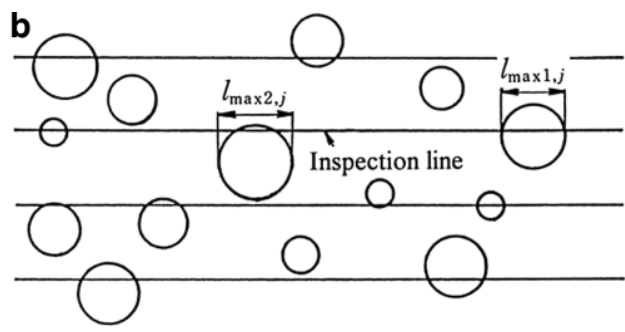

\section{Current state of knowledge}

\subsection{Non-metallic inclusions}

In the event of a crack initiation below the surface, common shot-peened gears made from case-carburized $\mathrm{MnCr}$ or CrNiMo-alloyed steels (e.g. $20 \mathrm{MnCr} 5$ or $18 \mathrm{CrNiMo} 7-6$ ) fail at typical main inclusions of two types: oblong manganese sulfides in MnCr-alloyed steels and spherical or oblong aluminum oxides in CrNiMo-alloyed steels (see Fig. 2; $[8,9])$.

Each material characterization is always done at random but should, of course, be representative of the steel batch. In industrial practice, six samples are usually inspected to determine the degree of cleanliness, for instance according to ISO 4967 [10], DIN 50602 [11] or SEP 1571 [12]. However, the distribution of non-metallic inclusions differs slightly, even within each individual steel batch. With the development of increasingly clean steels, it is becoming increasingly difficult to reliably determine the degree of cleanliness and the size and distribution of non-metallic inclusions. Murakami [13], for example, confirms that determination of the inspection plane affects the size and number of inclusions determined, see Fig. 3.

Melander et al. [14] demonstrate the influence of inclusion content on the fatigue strength of bearing steels and derive distribution functions for the inclusion densities. The assumption is that fewer and smaller inclusions reduce the probability of crack initiation at an inclusion and increase the fatigue strength. Tridello et al. [15, 16] also made use of this assumption. In several publications, a number of au- thors [17-21] derive competing distribution functions for different inclusion types. These distribution functions remain the subject of current research. To sum up, it is evident that the fatigue strength of shot-peened gears depends on the size and distribution of inclusions.

\subsection{Classic S-N curves}

In addition to the classic S-N curve known as the PalmgrenMiner original, there are also the Palmgren-Miner modified (or Haibach) approach and the Palmgren-Miner elementary approach (see Fig. 4). Standardized approaches for gears, such as ISO 6336, generally assume a classic S-N curve with either a constant endurance limit (PalmgrenMiner original) or a decreasing endurance limit (Palmgren-

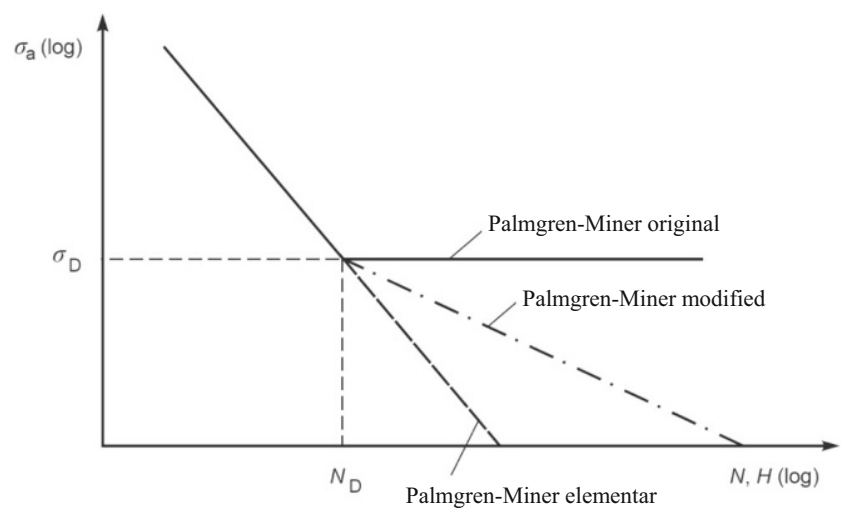

Fig. 4 Classic S-N curves for the high cycle fatigue range (acc. to [22] (translated)) 
Miner modified) for a higher number of load cycles. Crack initiation is always assumed to take place at the surface.

\subsection{Experimental results in and above the very high cycle fatigue regime}

The literature shows that in the very high cycle fatigue range of shot-peened specimens, crack initiation is often below the surface at non-metallic inclusions and, therefore, the fatigue strength decreases. This is documented for standard specimens (for example rotating bending, tensioncompression and thin-walled tube specimens) and gears, among others.

\subsubsection{Standard specimens}

Fig. 5 shows an example stepwise S-N curve for rotating bending specimens from Murakami et al. [23]. Failures with shot-peened standard specimens are also documented for between $10^{7}$ and $10^{9}$ load cycles, for example in studies by Toyoda et al. [24], Bathias et al. [25], Nakajima et al. [26], Thumser et al. [27], Sun et al. [28], Tridello et al. [16, 29, 30], Sandaiji and Tamura [31], and Nambu and Egami [32].

Wang et al. [33] and Tallerico and Cameron [34] even describe such failures for up to $10^{10}$ load cycles. Sakai [35] reviews studies on the VHCF of metallic materials for machine structural use, and summarizes and presents further investigations and their S-N curves. Fatigue failures in the

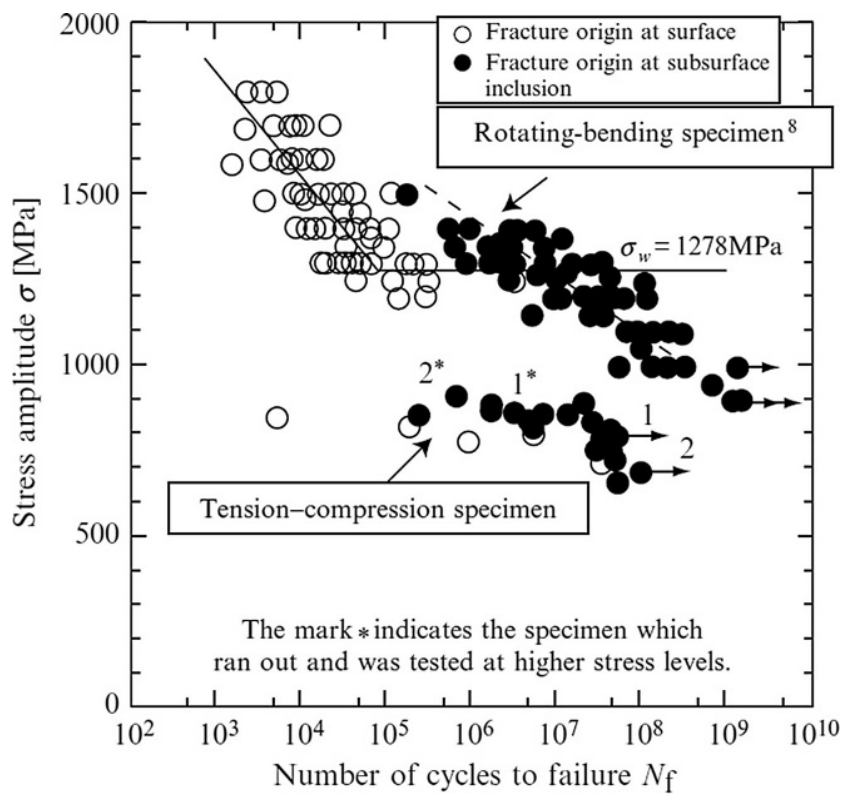

O: Specimen QT: Quenched and tempered

- : Specimen VQ: Heat treated in a vacuum followed by quenching and tempering

Fig. 5 Comparison of S-N data between rotating bending and tensioncompression [23]
VHCF range have also been documented for bearing steels [36], nitrocarburated specimens [37], austempered ductile iron (ADI) [38], dual-phase steels [39] and welded joints [40].

\subsubsection{Gears}

In the case of shot-peened gears, studies by Stenico [42] (based on [43]) and Bretl [41] (based on [44], published internationally in [45]), among others, display similar characteristics to those documented for standard specimens. The test results produced by Bretl [41] show foremost failures due to subsurface crack initiation at non-metallic inclusions up to $10^{8}$ load cycles (see Fig. 6). Not only is a decrease in the endurance fatigue life evident, it also seems that even with up to $10^{8}$ load cycles, there is still no endurance fatigue limit for shot-peened gears.

\subsection{Modified S-N curves in the VHCF range}

Nishijima and Kanazawa [46] show that even when shotpeened gears display increased bending strength in the high cycle fatigue range, a decrease in bending strength must be assumed at a higher number of load cycles. This results in a stepwise S-N-curve, as in Fig. 7b, unlike with the traditional concept shown in Fig. 7a or Fig. 4. The first part of the modified S-N curve represents the range comprising finite life and surface fatigue limit with crack initiation at the surface. The second part shows internal fatigue with an internal fatigue limit, which is defined by crack initiation below the surface at non-metallic inclusions.

Bathias presents a concept of a gigacycle fatigue S-N curve in [47], see Fig. 8. The author states that "only the

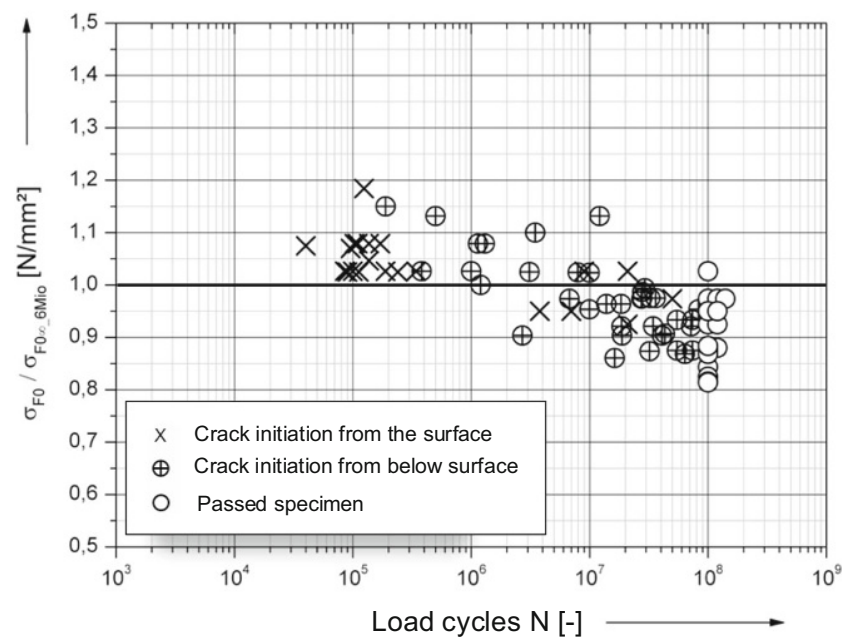

Fig. 6 Summary of results of various shot-peen tests reported in [41] (translated); (y-axis: ratio of nominal tooth root stress $\sigma_{\mathrm{F} 0}$ for each test point and nominal tooth root stress for $50 \%$ failure probability at a load cycle limit of 6 million $\sigma_{F 0} \infty \_6$ Mio for each variant) 
Fig. 7 Two S-N curve concepts according to Nishijima and Kanazawa [46]. a Traditional concept of an S-N curve. b The concept of a twofold S-N curve
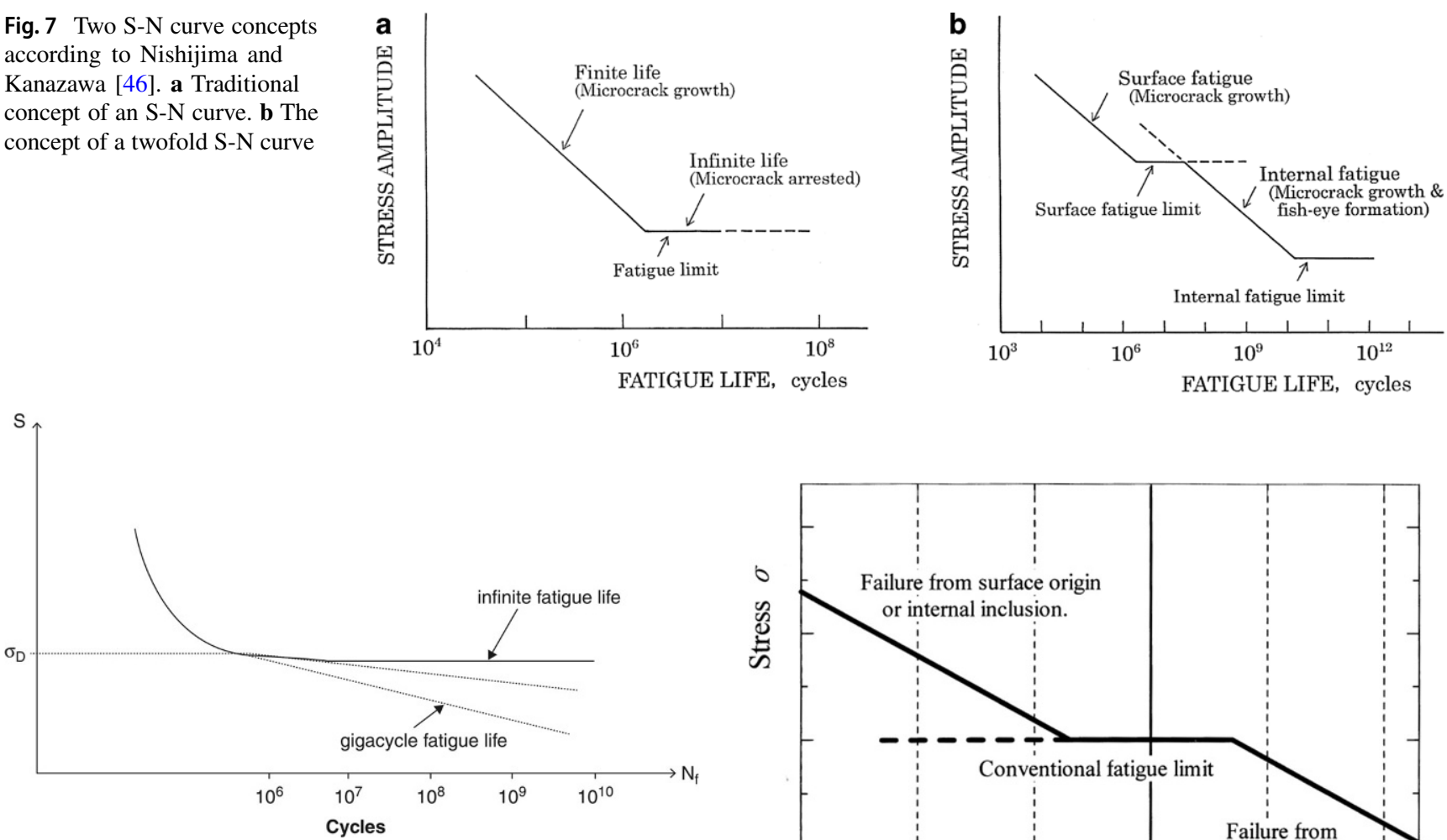

Fig. 8 Concept of a gigacycle fatigue S-N curve acc. to [47]

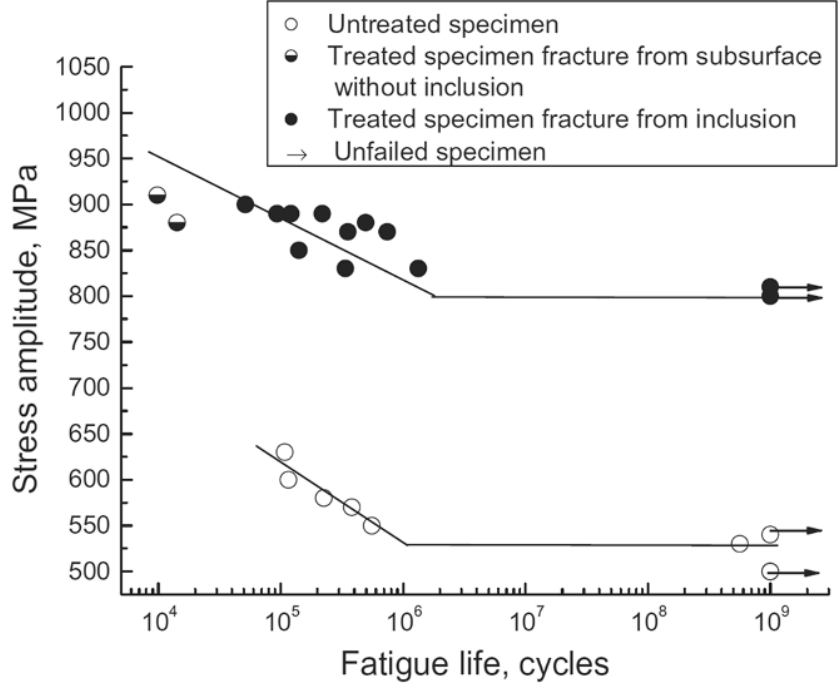

Fig. 9 S-N curve for nitrocarburized and post-oxidated specimen [37]

exploration of the life range between $10^{6}$ and $10^{10}$ cycles will create a safer approach to modeling ..." the S-N curve above the high cycle fatigue range. In [37], S-N curves are composed of only one inclined line and one horizontal line (fatigue limit) for nitrocarburized and post-oxidated standard specimens (see Fig. 9). The failures from inclusions were up to approximately $10^{6}$ load cycles.

Murakami et al. [48] define no second infinite fatigue limit for internal inclusions in the very high cycle fatigue

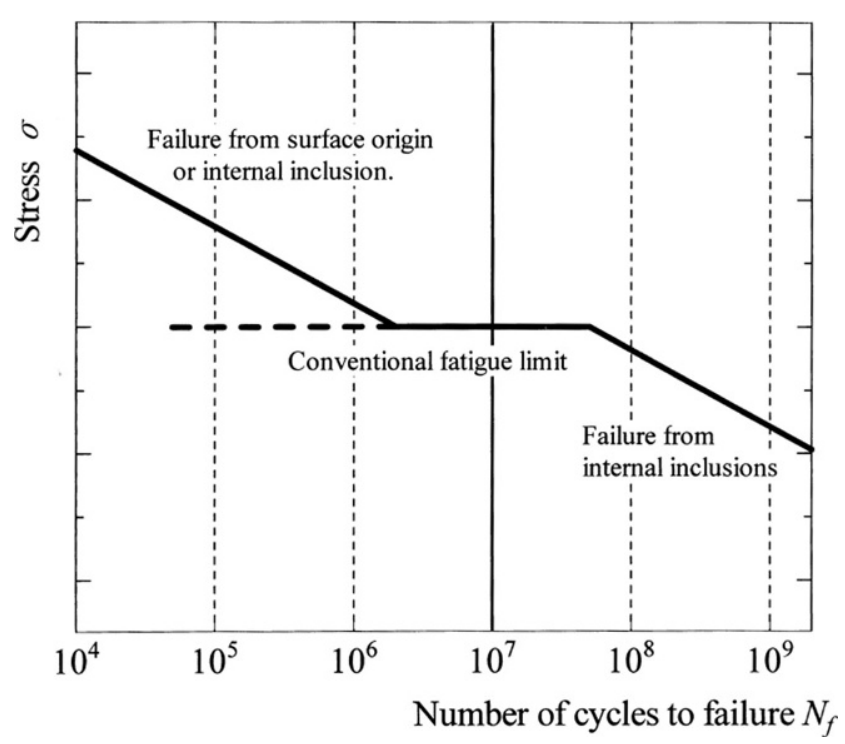

Fig. 10 Typical S-N curve for high strength steels [48]

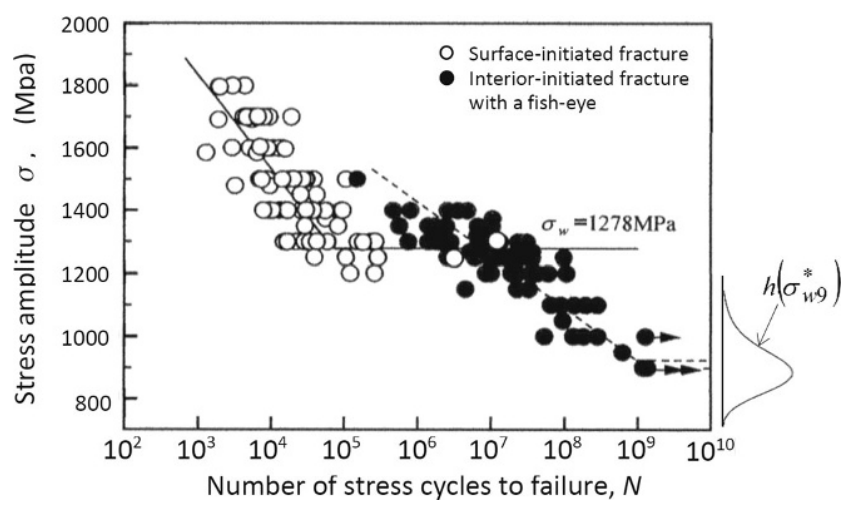

Fig. 11 Probability density and distribution functions of fatigue strength in the giga cycle fatigue range [35]

range, even above $10^{9}$ load cycles (see Fig. 10). This approach is also used by Mughrabi in [49, 50]. Murakami et al. state that "the transition from short to superlong fatigue life appears as a horizontal step in the S-N curve" and that the mechanism of fatigue fracture at superlong fatigue life has not yet been clarified. 


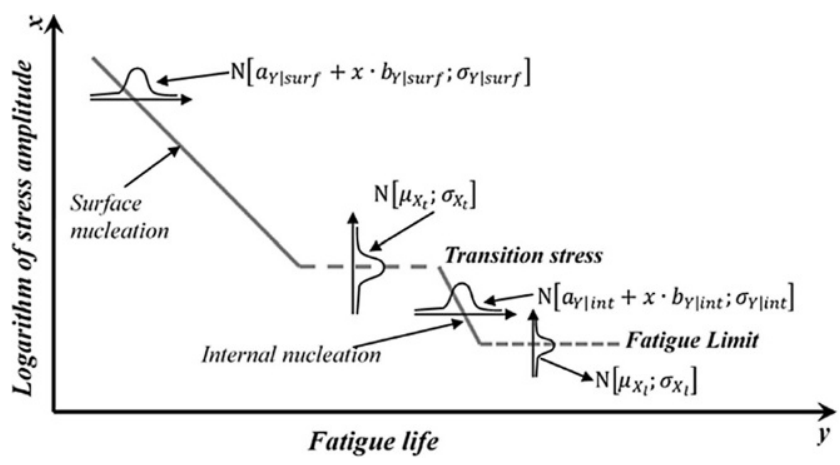

Fig. 12 Schematic diagram of a statistical Duplex S-N curve with fatigue limit [52]

\subsection{S-N curves based on stochastic distributions}

The S-N curve is generally based on a certain stochastic distribution in the infinite and finite fatigue ranges. On account of this, Nakamura et al. [51] derived a probability density and distribution functions of the fatigue strength in the gigacycle fatigue range of the test results of [35], see Fig. 11. Paolino et al. also presented a stepwise S-N curve in [52], based on a numerically estimated statistical distribution, with regard to the transition between high cycle fatigue (HCF) and very high cycle fatigue (VHCF), see Fig. 12. They derived mathematical correlations based on the experimental results.

\subsection{Summary of the current state of knowledge}

With case-carburized, shot-peened gears, crack initiation in and above the high cycle fatigue range typically occurs below the surface at non-metallic inclusions, due to the high compressive residual stresses introduced by the shot-peening process. This characteristic is influenced by the size and distribution of the inclusion. There are various competing techniques for determining an S-N curve above the highcycle fatigue range. However, the experimental results of standard specimens and gears indicate that even at up to
$10^{10}$ load cycles, no internal infinite or endurance fatigue limit can be assumed.

\section{Systematic investigations of the bending fatigue strength of case-carburized, shot- peened gears in the VHCF range}

\subsection{Material variants, test gears and test rigs}

The results of the experiment presented are based on research project [8] and the work done by Schurer [9]. The experimental results were published in part in [53], while a model approach considering the influence of non-metallic inclusions on the tooth root bending fatigue strength on the basis of these experimental results was published in [54, 55]. This project was conducted at the Gear Research Center (FZG) of the Technical University of Munich (TUM) in cooperation with steel producers, transmission manufacturers, automobile manufacturers, etc. For more information about the steel batches and their chemical compositions, degree of cleanliness, production routes and raw bar material diameters, see [55]. All steel batches displayed a high degree of cleanliness according to ISO 4967 method A [14] among others, and the chemical compositions of all variants were in accordance with the specifications in [56]. Table 1 provides a brief overview.

Extensive experiments were conducted to study fatigue behavior in gear tooth roots, especially in the very high cycle fatigue range. The tests were carried out on pulsator test rigs (normal module of $1.5 \mathrm{~mm}, 5 \mathrm{~mm}$ and $10 \mathrm{~mm}$ ) with additional tests being carried out on FZG back-to-back test rigs with a center distance of $\mathrm{a}=91.5 \mathrm{~mm}$ [57] (normal module of $1.5 \mathrm{~mm}$ (except V9)). The test rigs are shown in Fig. 13. In the pulsator test rig, the test gear is fixed between two clamps to cover a certain number of teeth, and two gear teeth are loaded by applying a pulsating bending force. The FZG back-to-back test rig operates according to a recirculating power loop principle to supply a fixed torque to a pair of test gears in the test gearbox [58].

Table 1 Overview of material variants investigated, gear sizes, and test rigs used

\begin{tabular}{|c|c|c|c|c|}
\hline Variant & $\mathrm{V} 1-\mathrm{V} 8$ & V9 & V10-V15, V18 & V16, V17 \\
\hline Material & $\begin{array}{l}16 \mathrm{MnCr} 5,20 \mathrm{MnCr} 5 \& \\
18 \mathrm{NiCr} 5-4\end{array}$ & & $\begin{array}{l}\text { 20MnCr5, } \\
\text { 18CrNiMo7-6 \& } \\
\text { 18CrMnMoNi9-5-5 }\end{array}$ & $18 \mathrm{CrNiMo} 7-6$ \\
\hline Production route & $\begin{array}{l}\text { Open melted \& electro-slag-remelted (ESR) } \\
\text { Continuous \& ingot casting }\end{array}$ & & & \\
\hline Normal module $\mathrm{m}_{\mathrm{n}}$ in $\mathrm{mm}$ & 1.5 & & 5 & 10 \\
\hline $\begin{array}{l}\text { Number of teeth of test } \\
\text { gear }\end{array}$ & Pinion: 59 & & 24 & 24 \\
\hline Test rig & $\begin{array}{l}\text { FZG back-to-back test rig \& pulsator test } \\
\text { rig }\end{array}$ & Pulsator test rig & & \\
\hline
\end{tabular}



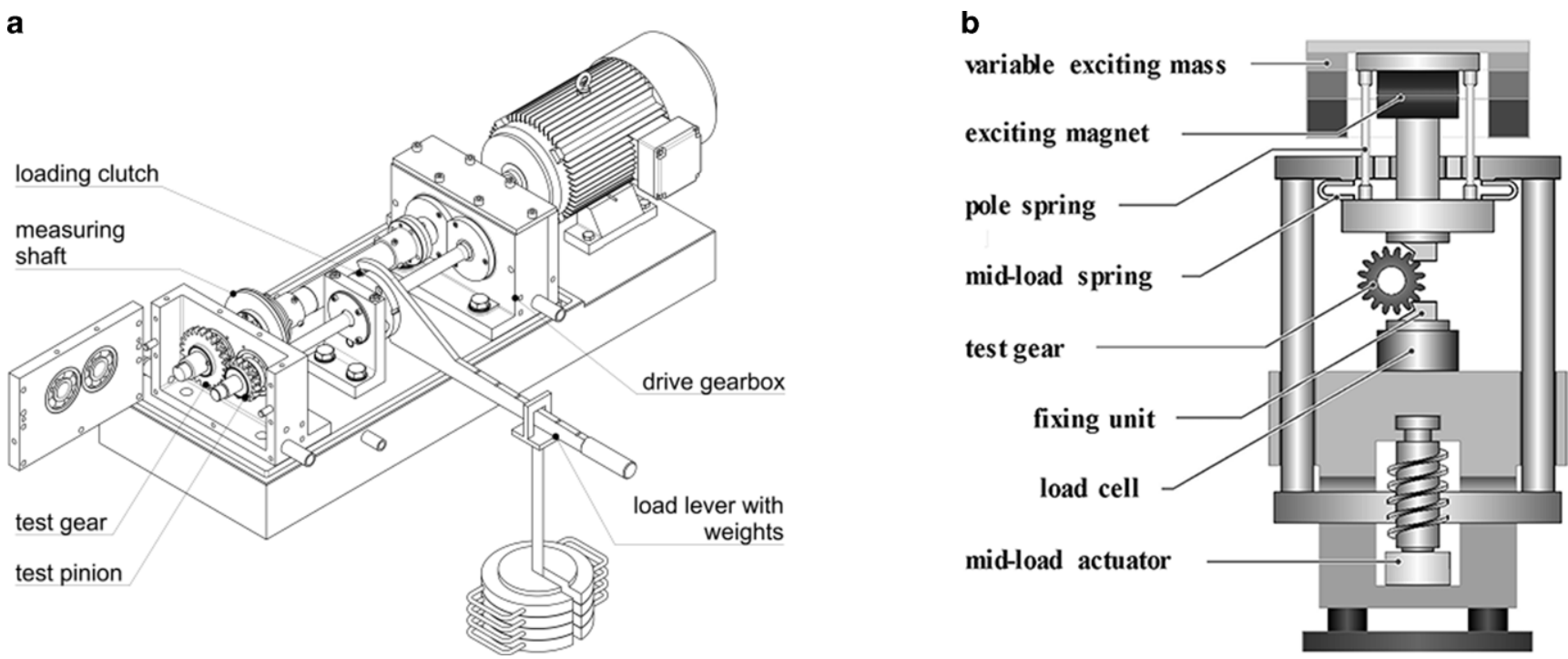

Fig. 13 Test rigs used for investigations on the tooth root bending strength. a FZG back-to-back test rig (center distance a=91.5 mm) [57]. b Pulsator test rig [8]
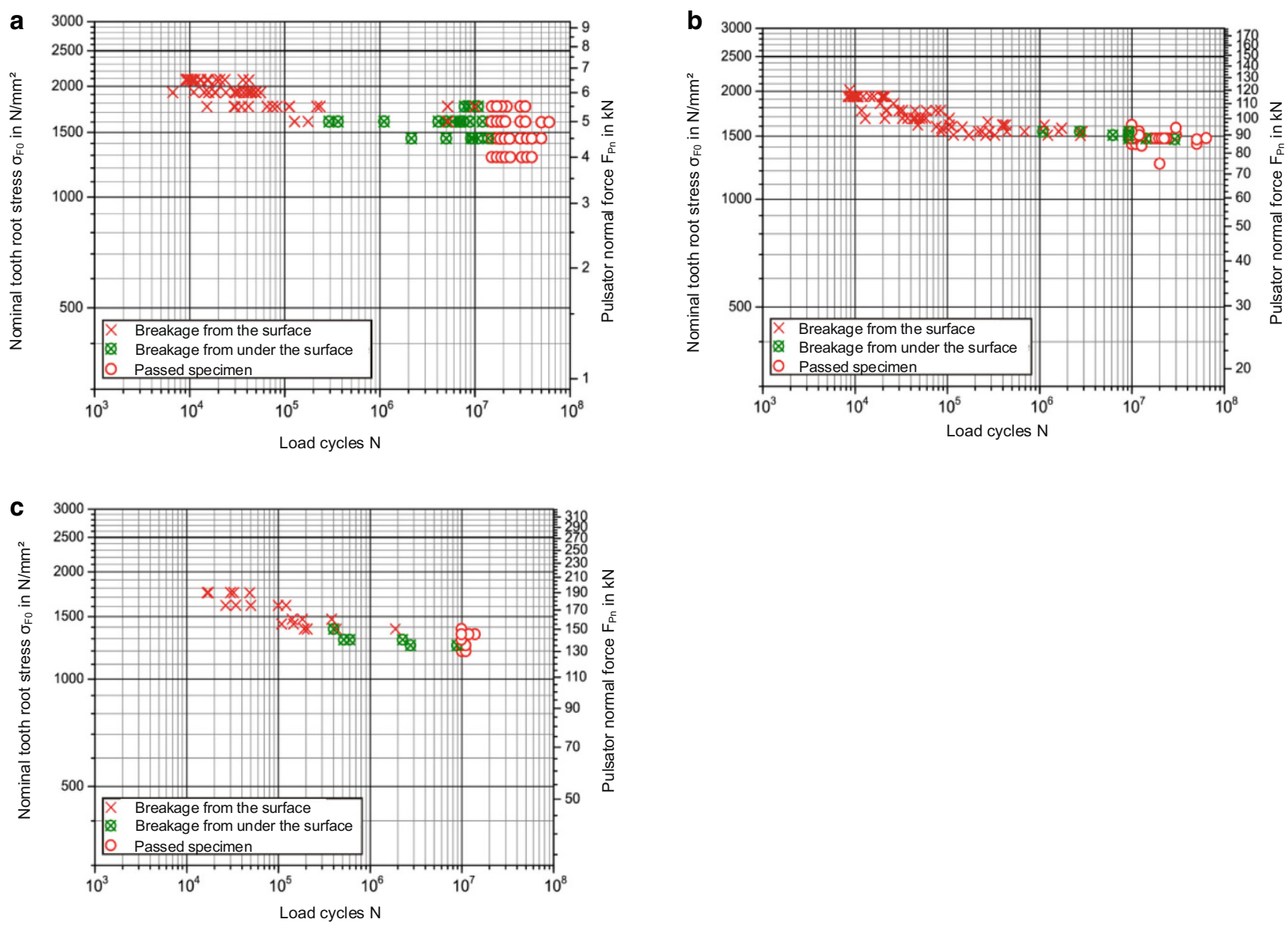

Fig. 14 Overview of experimental results on the pulsator test rig (overlapping test points of passed specimens are shifted towards a higher number of load cycles). a $\mathrm{m}_{\mathrm{n}}=1.5 \mathrm{~mm} . \mathbf{b} \mathrm{m}_{\mathrm{n}}=5 \mathrm{~mm} . \mathbf{c} \mathrm{m}_{\mathrm{n}}=10 \mathrm{~mm}$ 


\subsection{Experimental results}

When performing tooth root bending studies, the limiting number of load cycles for tests conducted on the pulsating test rig is commonly either 3 million (pursuant to ISO 6336-5 [6]) or 6 million (pursuant to FVA directive 563 I [7]). The limiting number of load cycles using the FZG back-to-back test rig to determine tooth root load carrying capacity is generally set to 10 million (see $[43,59]$ ). As shown in Sect. 2, no endurance fatigue limit can be assumed for shot-peened gears up to this number of load cycles. In the extensive experimental investigations on which this paper is based, the limiting numbers of load cycles were therefore set to:

\section{- Pulsator test rig:}

- Normal module $\mathrm{m}_{\mathrm{n}}=1.5 \mathrm{~mm}: 15 \cdot 10^{6}$ load cycles

- Normal module $\mathrm{m}_{\mathrm{n}}=5 \mathrm{~mm}: 10 \cdot 10^{6}$ load cycles

- Normal module $\mathrm{m}_{\mathrm{n}}=10 \mathrm{~mm}: 10 \cdot 10^{6}$ load cycles

- FZG back-to-back test rig: $30 \cdot 10^{6}$ load cycles

For some test points, the limiting number of load cycles was increased up to 60 million load cycles on the pulsator test rig and to 50 million load cycles on the FZG back-toback test rig (see Figs. 14 and 15). For the sake of clarity, overlapping test points of passed specimens were shifted towards a higher number of load cycles.

Non-metallic inclusions are statistically distributed in a material and to cause a failure, a critical non-metallic inclusion must be present at a critical distance from the surface. In the pulsating tests, the gears were clamped over two teeth for each test point, whereas on the FZG backto-back test rig, all 59 teeth of the pinion meshed with the wheel. This leads to a higher failure probability on the FZG back-to-back test rig because of the higher volume of material investigated and the greater probability of non-metallic inclusions appearing.

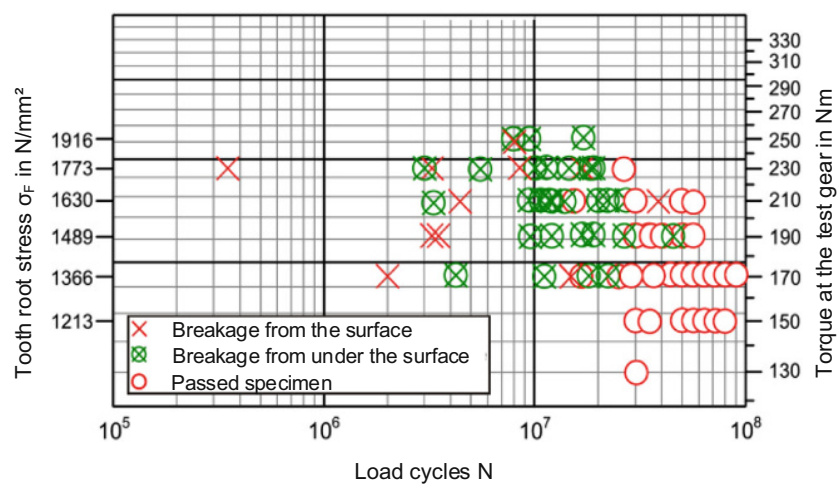

Fig. 15 Overview of all experimental results on the FZG back-to-back test rig (overlapping test points of passed specimens are shifted towards a higher number of load cycles)
Regarding the results of pulsating tests for the $1.5 \mathrm{~mm}$ gear module, Fig. 14 shows that most of the fractures initiated below the surface occurred up to 15 million load cycles. Above 15 million load cycles, no more failures occurred across all load levels. The $5 \mathrm{~mm}$ gear size shows a similar trend, with one late fracture just before 30 million load cycles. The $10 \mathrm{~mm}$ test gear module shows one fracture at a non-metallic inclusion near 10 million load cycles.

Considering the tests performed on the FZG back-toback test rig, the pattern is basically the same. Almost all fracture damage occurred above 10 million load cycles, at times reaching 45 million load cycles. Tests at load levels of 170 and $150 \mathrm{Nm}$ were halted after reaching a limiting number of load cycles 50 million.

To sum up, a further decrease in bending fatigue strength is apparent on the pulsator test rig above the standard limiting number of load cycles for all three gear sizes investigated. A further decrease can also be expected above the extended limiting number of load cycles. In addition, it can be assumed that on the FZG back-to-back test rig, fracture damage initiated at non-metallic inclusions from below the surface still occur above 50 million load cycles and the bending fatigue strength therefore begins to decrease again.

\section{Discussion}

For unpeened and most shot-blasted specimens, crack initiation occurs at the surface, and no significant decrease in endurance limit is expected at a higher number of load cycles (classic S-N curve-Palmgren-Miner original). However, as can be seen in Sect. 2, the transition from the high to the very high cycle fatigue range can be very different in shot-peened specimens with primarily fisheye failures. First, the start point and incline of the second step vary from material to material. Furthermore, for the range above 30 million load cycles, the progression of the curve has

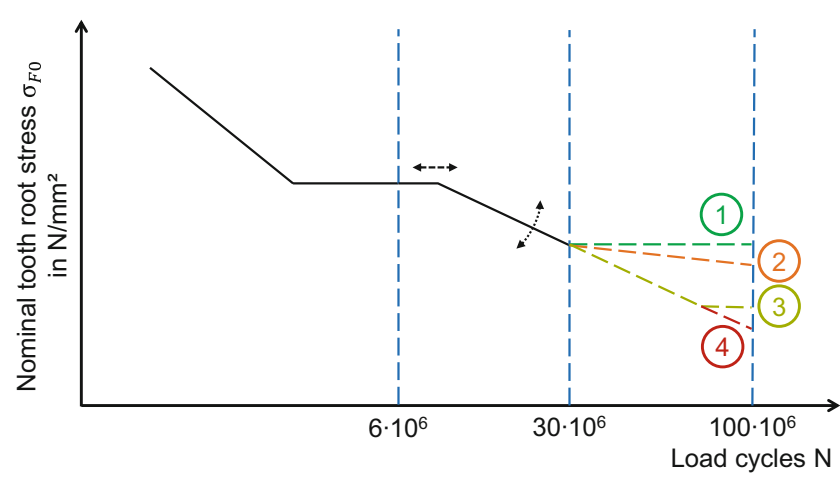

Fig. 16 Probable curve progressions beyond 30 million load cycles in the very high cycle fatigue range for shot-peened specimens with primarily fisheye failures 


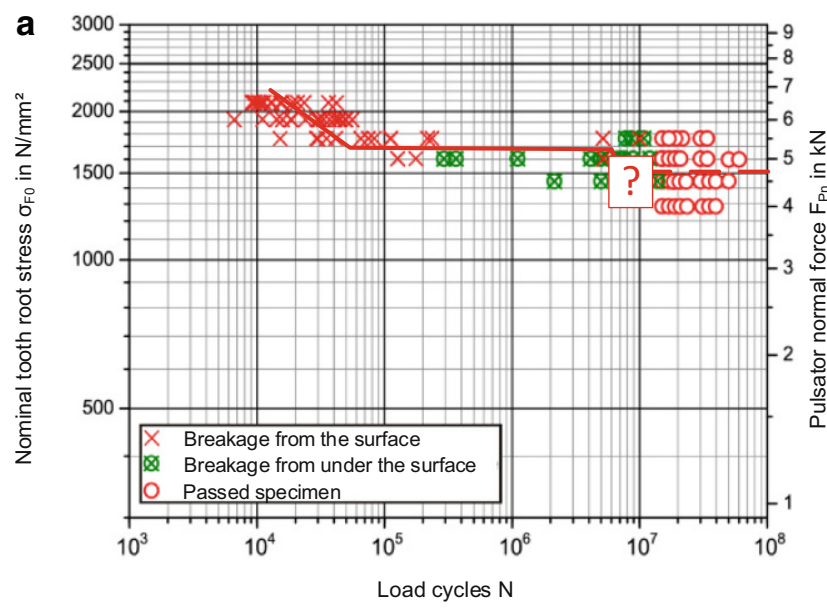

b

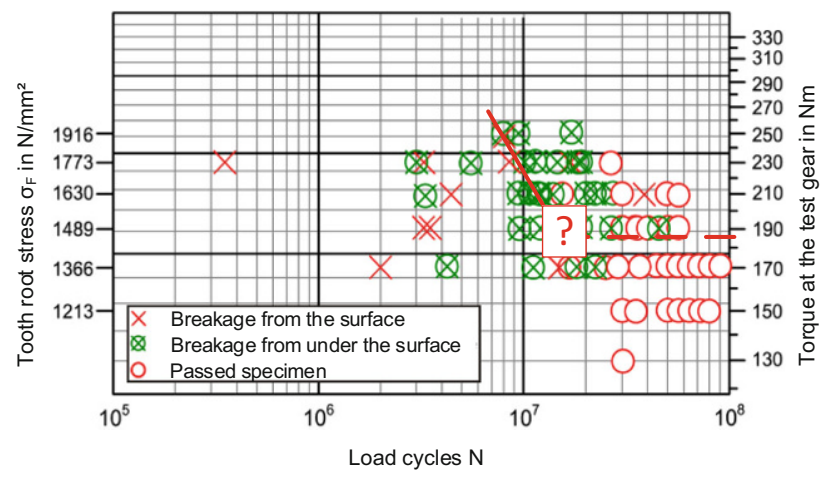

Fig. 17 Estimated stepwise S-N curves for a failure probability of approximately 50\% in the experimental results. a Results of pulsating test. b Results with FZG back-to-back test rig

not yet been verified for the bending strength of case-carburized, shot-peened gears with a crack initiation from below the surface at a non-metallic inclusion (fisheye failure). Fig. 16 presents some probable curve progressions beyond 30 million load cycles in the very high cycle fatigue range up to $10^{8} \mathrm{load}$ cycles. It could be that the progression for the presented experimental data resembles the schematic stepwise S-N curve with an internal fatigue strength such as (1). However, other progressions are also possible, such as (2) (different incline), (3) (internal fatigue limit at higher load cycles) and (4) (no internal fatigue limit).

So far, none of the approaches presented in Sect. 2 exactly match the experimental data basis of case-carburized, shot-peened gears with fisheye failures. Further experiments should be performed to investigate the range between 30 and 100 million load cycles in particular.

An initial estimation of a fatigue endurance limit for up to 15 million load cycles (pulsator tests) and 30 million load cycles (FZG back-to-back tests) is given in Fig. 17. The estimated S-N curve of the pulsating tests (see Fig. 17a) shows the first part of the stepwise S-N curve for surface fatigue up to the normal limiting number of load cycles. As the number of load cycles increases, the crack mechanism changes from fractures initiated from the surface to fractures initiated from below the surface at non-metallic inclusions. This is the range of the second step of the stepwise S-N curve. However, it cannot be determined how strong the decrease in bending fatigue strength will be or what incline the second limited lifetime has until the internal endurance fatigue limit is reached. Of course, the limiting number of load cycles can be increased on the pulsating test rig, but it is not certain, based on the distribution function, whether critical non-metallic inclusions are at a critical depth.

The first part of the stepwise S-N curve is also visible on the FZG back-to-back test rig; see Fig. 17b. However, based on the lower number of load cycles and the nonmetallic inclusion distribution, the results from the pulsator test rig show a higher estimated fatigue limit than that of the FZG back-to-back test rig. Therefore, to determine the bending fatigue strength for even higher numbers of load cycles it makes sense to use the FZG back-to-back test rig to examine a higher material volume.

\section{Conclusion}

The research findings reveal that no bending fatigue limit can be expected for shot-peened gears, even up to 50 million or 60 million load cycles, respectively. It was shown that the limiting number of load cycles should be increased to determine of the bending fatigue of shot-peened gears. Furthermore, no value could be assigned for a limiting number of load cycles that is sufficient for determining the endurance fatigue limit. The limiting number of load cycles on the pulsating test rig should be increased, but it is not certain if critical non-metallic inclusions are always present at a critical depth based on the distribution function. Based on the lower number of load cycles and the distribution of non-metallic inclusions, the pulsator test rig shows a higher estimated fatigue limit than that determined in the FZG back-to-back test rig. Therefore, in further investigations, it seems appropriate to conduct the test on the FZG back-toback test rig, due to the large number of meshing teeth in this test rig and to increase the number of load cycles to determine the bending fatigue strength to even higher load cycles. So far, none of the approaches presented in Sect. 2 exactly match the experimental data basis. Further investigations into gears should concentrate in particular on the range between 30 and 100 million load cycles. 
Acknowledgements The research work in [8] was funded in equal proportions by the "Arbeitsgemeinschaft industrieller Forschungsvereinigungen e. V. (AiF)", the German Federal Ministry of Economics and Technology (BMWi, IGF no. 16662 N) and the "Forschungsvereinigung Antriebstechnik e. V. (FVA)". The results presented in this paper were taken from the FVA research project 293 III "Späte Zahnfußbrüche/Reinheitsgrad" [8]. More detailed information on the influence of non-metallic inclusions is given in the final report. The research work in [44] was funded in equal proportions by the "Forschungsgemeinschaft der Eisen und Metall verarbeitenden Industrie e. V. (AVIF)" (A 220/2003) and the "Forschungsvereinigung Antriebstechnik e.V. (FVA)". The results presented in this paper were taken from the FVA research project 293 II "Späte Zahnfußbrüche" [44]. More detailed information on the influence of non-metallic inclusions is given in the final report.

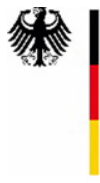

Bundesministerium

für Wirtschaft und Energie

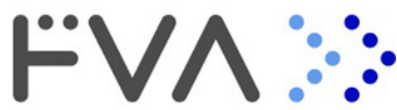

Forschungsvereinigung Antriebstechnik e.V.

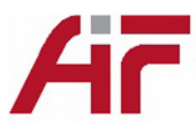

Forschungsnetzwerk Mittelstand

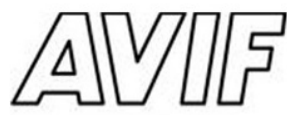

FORSCHUNGSVEREINIGUNG DE ARBETSSCEMEINSCHAFT DER EISEN UNO METALL VERARBETENOEN INDUSTRIE EV.

Funding Open Access funding enabled and organized by Projekt DEAL.

Open Access This article is licensed under a Creative Commons Attribution 4.0 International License, which permits use, sharing, adaptation, distribution and reproduction in any medium or format, as long as you give appropriate credit to the original author(s) and the source, provide a link to the Creative Commons licence, and indicate if changes were made. The images or other third party material in this article are included in the article's Creative Commons licence, unless indicated otherwise in a credit line to the material. If material is not included in the article's Creative Commons licence and your intended use is not permitted by statutory regulation or exceeds the permitted use, you will need to obtain permission directly from the copyright holder. To view a copy of this licence, visit http://creativecommons.org/licenses/by/4. $0 /$.

\section{References}

1. German Federal Office for Motor Vehicles (2010) Fahrzeugzulassungen - Neuzulassungen von Personenkraftwagen und Krafträdern nach Motorisierung Jahr 2009 [eng.: Vehicle registration-New registrations of passenger cars and motorcycles by engine in the year 2009]. German Federal Office for Motor Vehicles, Flensburg

2. German Federal Office for Motor Vehicles (2019) Fahrzeugzulassungen - Neuzulassungen von Personenkraftwagen und Krafträdern nach Motorisierung Jahr 2018 [eng.: Vehicle registration-New registrations of passenger cars and motorcycles by engine in the year 2018]. German Federal Office for Motor Vehicles, Flensburg

3. Diepart CP, Burrel NK (1987) Improved fatigue performance of gears through controlled shot peening. In: Third International Conference on Shot Peening, Garmisch-Partenkirchen, Germany

4. Epp J, Hirsch T, Zoch H-W (2013) Untersuchung und Bewertung von alternativen Oberflächenverfestigungsverfahren für gekerbte Bauteile [eng.: Investigation and evaluation of alternative surface strengthening methods for notched components]. FVA, vol 1063 (FVA project $605 \mathrm{I}$ )

5. Hirsch T (1983) Untersuchungen zur Zahnfußfestigkeit kugelgestrahlter Zahnräder [eng.: Investigations into the tooth root bending strength of shot-peened gears]

6. ISO (International Organization for Standardization) (2016) Calculation of load capacity of spur and helical gears-Part 5: strength and quality of materials (ISO6336-5)

7. Tobie T, Matt P (2012) Standardisation of load capacity tests: recommendations for the standardisation of load capacity tests on hardened and tempered cylindrical gears (FVA Directive 563 I)

8. Schurer S, Tobie T, Stahl K (2015) Tragfähigkeitsgewinn im Zahnfuß durch hochreine Stähle [eng.: Load carrying capacity increase in the tooth root due to ultra-clean steels]. FVA, vol 1148 (FVA research project 293 III)

9. Schurer S (2016) Einfluss nichtmetallischer Einschlüsse in hochreinen Werkstoffen auf die Zahnfußtragfähigkeit [eng.: Influence of non-metallic inclusions in ultra-clean materials on the tooth root load-carrying capacity]. Dissertation, Technical University of Munich

10. ISO (International Organization for Standardization) (1998) SteelDetermination of content of non-metallic inclusions-Micrographic method using standard diagrams (ISO4967)

11. DIN (Deutsches Insitut für Normung e. V.) (1985) Metallographic examination; microscopic examination of special steels using standard diagrams to assess the content of non-metallic inclusions (DIN 50602)

12. SEP (steel test specification) (2017) Evaluation of inclusions in special steels based on their surface areas-parts 1 to 3 (SEP1571)

13. Murakami Y (2002) Metal fatigue: effects of small defects and nonmetallic inclusions, 1st edn. Elsevier, Amsterdam

14. Melander A, Rolfsson M, Nordgren A et al (1991) Influence of inclusion contents on fatigue properties of SAE 52100 bearing steels. Scand J Metall 20:229-244

15. Tridello A, Paolino DS, Chiandussi G et al (2015) Different inclusion contents in H13 steel: effects on VHCF response of Gaussian specimens. KEM 665:49-52. https://doi.org/10.4028/www. scientific.net/KEM.665.49

16. Tridello A, Paolino DS, Chiandussi G et al (2016) VHCF strength decrement in large H13 steel specimens subjected to ESR process. Procedia Struct Integr 2:1117-1124. https://doi.org/10.1016/ j.prostr.2016.06.143

17. Shi G, Atkinson HV, Sellars CM et al (1999) Application of the generalized pareto distribution to the estimation of the size of the maximum inclusion in clean steels. Acta Mater 47:1455-1468. https:// doi.org/10.1016/S1359-6454(99)00034-8

18. Atkinson HV, Shi G (2003) Characterization of inclusions in clean steels: a review including the statistics of extremes methods. Prog Mater Sci 48:457-520. https://doi.org/10.1016/S00796425(02)00014-2

19. Beretta S, Murakami Y (1998) Statistical analysis of defects for fatigue strength predicition and quality control of materials. Fat 
Frac Eng Mat Struct 21:1049-1065. https://doi.org/10.1046/j.14602695.1998.00104.x

20. Beretta S, Murakami Y (2001) Largest-extreme-value distribution analysis of multiple inclusion types in determining steel cleanliness. Metall Mater Trans B 32:517-523. https://doi.org/10.1007/s11663001-0036-4

21. Beretta S, Anderson C, Murakami Y (2006) Extreme value models for the assessment of steels containing multiple types of inclusion. Acta Mater 54:2277-2289. https://doi.org/10.1016/j.actamat.2006. 01.016

22. Sander M (2018) Sicherheit und Betriebsfestigkeit von Maschinen und Anlagen [eng.: Safety and fatigue strength of machinery and systems]. Springer, Berlin, Heidelberg, New York

23. Murakami Y, Yokoyama NN, Nagata J (2002) Mechanism of fatigue failure in ultralong life regime. Fat Frac Eng Mat Struct 25:735-746. https://doi.org/10.1046/j.1460-2695.2002.00576.x

24. Toyoda T, Kaazawa T, Hisamatus S (1993) Influence of inclusions on the fatigue strength of shot peened carburized steel. In: Conf Proc: ICSP-5, pp 333-340

25. Bathias C, Drouillac L, Le François P (2001) How and why the fatigue $\mathrm{S}-\mathrm{N}$ curve does not approach a horizontal asymptote. Int J Fatigue 23:143-151. https://doi.org/10.1016/S0142-1123(01)001232

26. Nakajima M, Kamiya N, Itoga H et al (2006) Experimental estimation of crack initiation lives and fatigue limit in subsurface fracture of a high carbon chromium steel. Int J Fatigue 28:1540-1546. https://doi.org/10.1016/j.ijfatigue.2005.05.017

27. Thumser R, Kleemann S, Bergmann JW et al (2012) Investigation on defect distribution and its statistical evaluation for case hardened material states. Int J Fatigue 41:52-56. https://doi.org/10.1016/j. ijfatigue.2012.01.024

28. Sun C, Lei Z, Xie J et al (2013) Effects of inclusion size and stress ratio on fatigue strength for high-strength steels with fish-eye mode failure. Int J Fatigue 48:19-27. https://doi.org/10.1016/j.ijfatigue. 2012.12.004

29. Tridello A, Paolino DS, Chiandussi G et al (2015) Ultrasonic VHCF tests on AISI H13 steel with two different inclusion content: assessment of size effects with gaussian specimens. Procedia Eng 109:121-127. https://doi.org/10.1016/j.proeng.2015.06.218

30. Tridello A, Fiocchi J, Biffi CA et al (2019) VHCF response of heattreated SLM Ti6Al4V Gaussian specimens with large loaded volume. Procedia Struct Integr 18:314-321. https://doi.org/10.1016/j. prostr.2019.08.171

31. Sandaiji Y, Tamura E (2017) Influence of loading type on fracture behaviour of high strength steel under very high cycle fatigue. In: Zimmermann M, Christ H-J (eds) VHCF7: Seventh International Conference on Very High Cycle Fatigue: July 3-5, 2017, Dresden, Germany. Universität Lehrstuhl für Materialkunde und Werkstoffprüfung, Siegen, pp 25-30

32. Nambu K, Egami N (2017) Influence of hybrid surface modification on very high cycle fatigue strength of various steel materials. In: Zimmermann M, Christ H-J (eds) VHCF7: Seventh International Conference on Very High Cycle Fatigue: July 3-5, 2017, Dresden, Germany. Universität Lehrstuhl für Materialkunde und Werkstoffprüfung, Siegen, pp 302-307

33. Wang Q, Bathias C, Kawagoishi N et al (2002) Effect of inclusion on subsurface crack initiation and gigacycle fatigue strength. Int J Fatigue 24:1269-1274. https://doi.org/10.1016/S0142-1123(02) 00037-3

34. Tallerico TF, Cameron ZA (2019) Ultrasonic gear steel fatigue at NASA

35. Sakai T (2009) Review and prospects for current studies on very high cycle fatigue of metallic materials for machine structural use. JMMP 3:425-439. https://doi.org/10.1299/jmmp.3.425

36. Zhao A, Xie J, Sun C et al (2012) Effects of strength level and loading frequency on very-high-cycle fatigue behavior for a bear- ing steel. Int J Fatigue 38:46-56. https://doi.org/10.1016/j.ijfatigue. 2011.11.014

37. Zhang JW, Lu LT, Shiozawa K et al (2011) Effect of nitrocarburizing and post-oxidation on fatigue behavior of $35 \mathrm{CrMo}$ alloy steel in very high cycle fatigue regime. Int J Fatigue 33:880-886. https:// doi.org/10.1016/j.ijfatigue.2011.01.016

38. Zammit A, Mhaede M, Grech M et al (2012) Influence of shot peening on the fatigue life of $\mathrm{Cu}-\mathrm{Ni}$ austempered ductile iron. Mater Sci Eng A 545:78-85. https://doi.org/10.1016/j.msea.2012.02.092

39. Torabian N, Favier V, Dirrenberger J et al (2017) Investigation of the response of dual-phase steels submitted to $20 \mathrm{KHz}$ and low frequency fatigue loadings. In: Zimmermann M, Christ H-J (eds) VHCF7: Seventh International Conference on Very High Cycle Fatigue: July 3-5, 2017, Dresden, Germany. Universität Lehrstuhl für Materialkunde und Werkstoffprüfung, Siegen, pp 368-373

40. Zhu M-L, Xuan F-Z, Du Y-N et al (2012) Very high cycle fatigue behavior of a low strength welded joint at moderate temperature. Int J Fatigue 40:74-83. https://doi.org/10.1016/j.ijfatigue.2012.01. 014

41. Bretl NT (2010) Einflüsse auf die Zahnfußtragfähigkeit einsatzgehärteter Zahnräder im Bereich hoher Lastspielzahlen [eng.: Influences on the tooth root load carrying capacity of case-hardened gears in the range of high load cycles]. Dissertation, Technical University of Munich

42. Stenico A (2007) Werkstoffmechanische Untersuchungen zur Zahnfußtragfähigkeit einsatzgehärteter Zahnräder [eng.: Material-mechanical investigations of the tooth root load carrying capacity of case-hardened gears ]. Dissertation, Technical University of Munich

43. Stenico A, Krug T, Oster P et al (2004) Eigenspannungseinfluss auf die Zahnfußtragfähigkeit kleinmoduliger Zahnräder [eng.: Residual stress influence on the tooth root load carrying capacity of smallmodulus gears]. FVA, vol 745 (FVA project 369 I+II)

44. Bretl NT, Tobie T, Höhn B-R (2008) Einflüsse auf die Zahnfußtragfähigkeit einsatzgehärteter Zahnräder im Bereich hoher Lastspielzahlen [eng.: Influences on the tooth root load carrying capacity of case-hardened gears in the range of high load cycles]. FVA, vol 851 (FVA project 293 II)

45. Bretl N, Schurer S, Tobie T et al (2013) Investigations on tooth root bending strength of case hardened gears in the range of high cycle fatigue. AGMA Technical Paper, vol 13FTM09

46. Nishijima S, Kanazawa K (1999) Stepwise SN curve and fisheye failure in gigacycle fatigue. Fat Frac Eng Mat Struct 22:601-607. https://doi.org/10.1046/j.1460-2695.1999.00206.x

47. Bathias C (2013) Fatigue limit. In: Wang QJ, Chung Y-W (eds) Encyclopedia of tribology. Springer US, Boston, pp 1041-1052

48. Murakami Y, Nomoto T, Ueda T (1999) Factors influencing the mechanism of superlong fatigue failure in steels. Fat Frac Eng Mat Struct 22:581-590. https://doi.org/10.1046/j.1460-2695.1999. 00187.x

49. Mughrabi H (1999) On the lifecontrolling microstructural fatigue mechanisms in ductile metals and alloys in the gigacycle regime. Fat Frac Eng Mat Struct 22:633-641. https://doi.org/10.1046/j. 1460-2695.1999.00186.x

50. Mughrabi H (2002) On 'multi-stage' fatigue life diagrams and the relevant life-controlling mechanisms in ultrahigh-cycle fatigue. Fat Frac Eng Mat Struct 25:755-764. https://doi.org/10.1046/j.14602695.2002.00550.x

51. Nakamura Y, Sakai T, Harlow D et al (2017) Probabilistic model on statistical fatigue property in very high cycle regime based on distributions of size and location of interior inclusions. In: Zimmermann M, Christ H-J (eds) VHCF7: Seventh International Conference on Very High Cycle Fatigue: July 3-5, 2017, Dresden, Germany. Universität Lehrstuhl für Materialkunde und Werkstoffprüfung, Siegen, pp 81-86 
52. Paolino DS, Tridello A, Geng HS et al (2014) Duplex S-N fatigue curves: statistical distribution of the transition fatigue life. Frat Ed Integr Strutt 8:417-423. https://doi.org/10.3221/IGF-ESIS.30.50

53. Winkler KJ, Schurer S, Tobie $T$ et al (2019) Investigations on the tooth root bending strength and the fatigue fracture characteristics of case-carburized and shot-peened gears of different sizes. Proc Inst Mech Eng Part C J Mech Eng Sci. https://doi.org/10.1177/ 0954406219841650

54. Fuchs D, Schurer S, Tobie T et al (2019) A model approach for considering nonmetallic inclusions in the calculation of the local tooth root load-carrying capacity of high-strength gears made of high-quality steels. Proc Inst Mech Eng Part C J Mech Eng Sci. https://doi.org/10.1177/0954406219840676

55. Fuchs D, Schurer S, Tobie T et al (2019) Investigations into nonmetallic inclusion crack area characteristics relevant for tooth root fracture damages of case carburised and shot-peened high strength gears of different sizes made of high-quality steels. Forsch Ingenieurwes. https://doi.org/10.1007/s10010-019-00324-x

56. DIN (Deutsches Insitut für Normung e. V.) (2019) Heat-treatable steels, alloy steels and free-cutting steels-Part 3: case-hardening steels (DIN EN ISO683-3)

57. DIN (Deutsches Insitut für Normung e. V.) (2006) Gears-FZG test procedures-Part 1: FZG test method A/8,3/90 for relative scuffing load-carrying capacity of oils (DIN ISO14635-1)

58. DIN (Deutsches Insitut für Normung e. V.) (1990) Testing of lubricants; FZG gear test rig; general working principles (DIN 513541)

59. Pollaschek J, Weber C, Löpenhaus C et al (2018) Lokale Zahnfußtragfähigkeit von Stirnrädern bei Biegewechsellast [eng.: Local tooth root load carrying capacity of spur gears under alternating bending load]. FVA, vol 1280 (FVA project 718 I) 